\title{
Article \\ Detection of E. coli Bacteria in Milk by an Acoustic Wave Aptasensor with an Anti-Fouling Coating
}

\author{
Sandro Spagnolo ${ }^{1}$, Brian De La Franier ${ }^{2}$, Katharina Davoudian ${ }^{2}$, Tibor Hianik ${ }^{1} \mathbb{D}$ and Michael Thompson ${ }^{2, * \mathbb{D}}$ \\ 1 Faculty of Mathematics, Physics and Information, Comenius University, Mlynská dolina F1, \\ 84248 Bratislava, Slovakia; sandrospagnolo1@gmail.com (S.S.); tibor.hianik@fmph.uniba.sk (T.H.) \\ 2 Department of Chemistry, University of Toronto, 80 St. George Street, Toronto, ON M5S 3H6, Canada; \\ brian.delafranier@mail.utoronto.ca (B.D.L.F.); k.davoudian@mail.utoronto.ca (K.D.) \\ * Correspondence: m.thompson@utoronto.ca; Tel.: +1-416-978-3575
}

\section{check for \\ updates}

Citation: Spagnolo, S.; De La Franier,

B.; Davoudian, K.; Hianik, T.;

Thompson, M. Detection of E. coli

Bacteria in Milk by an Acoustic Wave

Aptasensor with an Anti-Fouling

Coating. Sensors 2022, 22, 1853.

https://doi.org/10.3390/s22051853

Academic Editors: Artur J. Moro, Bruno Pedras, Hugo Miguel Santos and Shyqyri Haxha

Received: 18 January 2022

Accepted: 23 February 2022

Published: 26 February 2022

Publisher's Note: MDPI stays neutral with regard to jurisdictional claims in published maps and institutional affiliations.

Copyright: (c) 2022 by the authors. Licensee MDPI, Basel, Switzerland. This article is an open access article distributed under the terms and conditions of the Creative Commons Attribution (CC BY) license (https:/ / creativecommons.org/licenses/by/ $4.0 /)$.

\begin{abstract}
Milk is a significant foodstuff around the world, being produced and consumed in large quantities. The safe consumption of milk requires that the liquid has an acceptably low level of microbial contamination and has not been subjected to spoiling. Bacterial safety limits in milk vary by country but are typically in the thousands per $\mathrm{mL}$ of sample. To rapidly determine if samples contain an unsafe level of bacteria, an aptamer-based sensor specific to Escherichia coli bacteria was developed. The sensor is based on an ultra-high frequency electromagnetic piezoelectric acoustic sensor device (EMPAS), with the aptamer being covalently bound to the sensor surface by the anti-fouling linker, MEG-Cl. The sensor is capable of the selective measurement of E. coli in PBS and in cow's milk samples down to limits of detection of 35 and $8 \mathrm{CFU} / \mathrm{mL}$, respectively, which is well below the safe limits for commercial milk products. This sensing system shows great promise for the milk industry for the purpose of rapid verification of product safety.
\end{abstract}

Keywords: E. coli; biosensor; anti-fouling; MEG-Cl; aptamer; acoustic wave sensor; milk

\section{Introduction}

Milk is a highly important foodstuff, with the European Union producing over 160 million tons of milk each year [1]. For milk to be safe for consumption it must be reasonably free of harmful microbes, such as Escherichia coli (E. coli) or Staphylococcus aureus (S. aureus), which could render illness in consumers. For example, foodborne Shiga toxin-producing E. coli (STEC) can cause mild to severe clinical conditions, including acute gastroenteritis and hemolytic uremic syndrome [2,3]. In Europe, approximately 6\% of STEC cases result from dairy consumption [2]. An increasing interest in raw drinking milk (RDM) poses further health risks from STEC and other foodborne pathogens. Pathogenic contamination in RDM can have additional health risks, especially as bovine antibiotic use can lead to antimicrobial-resistant bacteria in milk [4,5].

In the European Union countries, the safe limit of bacterial contamination in milk is $10^{5}$ colony-forming units $/ \mathrm{mL}(\mathrm{CFU} / \mathrm{mL})$, with less than $1.5 \times 10^{4} \mathrm{CFU} / \mathrm{mL}$ being desirable [6]. The number of bacteria in milk samples is generally measured by using agar plate counts [7], with typically thousands of bacterial colonies found per milliliter of sample. This is achieved by spreading a small amount of sample on an agar plate, either on its own or diluted, and incubating it at $37^{\circ} \mathrm{C}$ overnight. Any live bacteria should grow into a visible colony in that time and can be counted either by hand or using computer imaging software. However, this requirement of an overnight assay to obtain results followed by accurate counting of small colonies makes this measurement slow and somewhat unreliable.

The development of a rapid biosensor, which could quantify the number of bacteria present in milk samples, would greatly improve the accuracy and rapidity of milk safety evaluation to determine if samples contain an unsafe quantity of bacteria. To do so, a sensor probe for the bacterial species of interest would need to be covalently bound to a sensor surface. 
Among the perspective probes for recognition of bacteria, the DNA aptamers are of substantial interest. They are single-stranded oligonucleotides developed by combinatorial chemistry using the method called SELEX (Systematic Evolution of Ligands by Exponential Enrichment). This method has been originally developed for the detection of proteins, such as thrombin or small molecules, for example, fluorescence dyes. However, it can also be useful for the detection of whole bacteria, cells, or viruses. This modification of SELEX is known as Cell-SELEX. In this method, the aptamers are selected in particular for a certain protein in the cell membrane [8]. The aptamer in a solution folds into a 3D structure, forming a binding site for the corresponding analyte. In contrast with antibodies that were also used for the development of affinity bacterial sensors [9], the aptamers have several advantages. They can be developed in vitro for a practically unlimited number of different compounds. They are also not immunogenic and are more stable than antibodies. Once the aptamer oligonucleotide sequence is developed it can be reproduced with high precision using standard oligonucleotide synthesis. Aptamers can be modified by various compounds which increase their stability toward cleavage by nucleases and allow their immobilization at various surfaces [10].

The aptamers sensitive to $E$. coli, which is a very common milk contaminant [11-14], have been used so far mostly for the development of electrochemical [10,15] and optical [16,17] aptasensors. There is, however, only a limited number of papers published so far on E. coli detection by acoustics methods. In the paper by Urmann et al. [18] the thiolated aptamers with the same sequence as those used in our work have been chemisorbed on a quartz crystal microbalance (QCM) transducer. The limit of detection (LOD) for E. coli has been determined as $10^{6} \mathrm{CFU} / \mathrm{mL}$. Yu et al. [13] reported a LOD of $1.46 \times 10^{3} \mathrm{CFU} / \mathrm{mL}$ for E. coli O157:H7 detection by QCM. Most recently, Khobragade et al. [19] achieved a LOD of $10^{4} \mathrm{CFU} / \mathrm{mL}$ for E. coli using aptasensors based on a non-linear quartz crystal resonator method (QCR).

In this work, we applied DNA aptamers specific to E. coli for the development of an acoustic wave sensor based on ultrathin quartz discs called an electromagnetic piezoelectric acoustic sensor (EMPAS) [20], which operates at very high frequencies, around $1 \mathrm{GHz}$. To obtain accurate measurements, any non-specific adsorption of foreign material, often termed fouling, needs to be prevented so a signal change is due to the analyte of interest [21]. Many strategies have been employed to reduce sensor fouling, with the use of surfaceassembled monolayers being very common [22-24].

We have developed a very promising ultra-thin anti-fouling coating, from hydrolyzed 2-(3-trichlorosilylpropyloxy)-ethyl trifluoroacetate (MEG-OH), which has successfully been used to dramatically reduce fouling from various biological agents [25-27]. To attach sensor probes to surfaces, a similar compound was developed which contains a highly reactive acyl chloride terminal functionality, 3-(3-(trichlorosilylpropyloxy) propanoyl chloride (MEG$\mathrm{Cl}$ ) [28]. This coating was found to reduce surface fouling of EMPAS sensors from milk to a large degree, opening the possibility of developing sensors that can function in real samples [28].

In this work, MEG-Cl was used to bind the E. coli selective aptamer to the sensing surface of EMPAS quartz crystals to quantify the number of bacteria in either buffer or milk samples. The goal of research on this sensor is to not only detect the presence of E. coli bacteria in milk samples, but also to quantify the number of bacteria on a selective basis.

\section{Materials and Methods}

\subsection{Materials}

MEG-Cl was synthesized according to previously published methods [28,29]. Anhydrous toluene and pyridine were purchased from Sigma-Aldrich (St. Louis, MO, USA). The DNA aptamer was obtained in lyophilized form from Biosearch Technologies (Risskov, Denmark) and is represented by an amine-terminated oligonucleotide at the $5^{\prime}$ end. The sequence of the aptamer used has been taken from [30]: $5^{\prime}-\mathrm{NH}_{2}-\mathrm{ATC}$ CGT CAC ACC TGC TCT ACG GCG CTC CCC AAC AGG CCT CTC CTT ACG GCA TAT TAT GGT GTT GGC TCC CGT AT-3'. Ethanol was obtained from Caledon Laboratory Chemicals (Georgetown, 
ON, Canada). All chemicals were used without further purification. UHT cow's milk, 3.5\% fat, was purchased from Walmart (Toronto, Canada). Adhesion experiments were carried out with Escherichia coli DH5 $\alpha$, Pseudomonas aeruginosa PAO1, and Staphylococcus aureus KR3 purchased from the University of Toronto Medstore (Toronto, ON, Canada).

\subsection{Preparation of Aptamer Stock Solution}

The DNA aptamer was originally selected for the outer membrane proteins of the E. coli 8379 strain [30]. However, because these proteins are common for various E. coli strains [30], including those used in our experiments (E. coli $\mathrm{DH} 5 \alpha)$, we applied this aptamer in the sensor development. Before use, the aptamer was re-suspended in a $\mathrm{pH}$ 8.0 TE buffer containing $10 \mathrm{mM}$ Tris- $\mathrm{Cl}$ and $1 \mathrm{mM}$ EDTA in DNase-free water to obtain a $100 \mu \mathrm{M}$ concentration of the initial stock solution. Subsequently, a portion of the stock solution thus obtained was diluted 10 times to a working concentration of $10 \mu \mathrm{M}$ with PBS buffer and divided in $100 \mu \mathrm{L}$ volume aliquots into single-use micro-vials, stored at $-20{ }^{\circ} \mathrm{C}$ until use at the desired concentration for only one experiment.

\subsection{Cleaning and Surface Modification of Quartz Crystals}

The procedures in Section 2.3 have been previously published in a paper for which this work is a continuation [29]. Quartz crystals (AT-cut, $13 \mathrm{~mm}$ in diameter, $\mathrm{t}=83 \mu \mathrm{m}$ thickness, $20 \mathrm{MHz}$ fundamental frequency) purchased from Laptech Precision Inc. (Bowmanville, Ontario, Canada), were rinsed according to the previously published methods in $1 \%$ sodium dodecyl sulphate (SDS, Sigma-Aldrich, St. Louis, MO, USA), then rinsed by tap water, and subsequently in distilled water. The crystals were then individually soaked in $6 \mathrm{~mL}$ pre-heated to $90{ }^{\circ} \mathrm{C}$ Piranha solution (3:1 v/v mixture of $98 \% \mathrm{H}_{2} \mathrm{SO}_{4}$ and $30 \% \mathrm{H}_{2} \mathrm{O}_{2}$ ), using a water bath for $30 \mathrm{~min}$. They were then rinsed in distilled water followed by methanol and sonicated for $2 \mathrm{~min}$ in another portion of methanol. After this, they were rinsed again with methanol, then dried by placing them in an oven at $150{ }^{\circ} \mathrm{C}$ for $2 \mathrm{~h}$. They were then plasma cleaned for $15 \mathrm{~min}$ to increase surface hydroxylation and transferred into a humidity chamber (70-80\% RH, room temperature) for overnight surface hydration.

The following day the crystals were submerged in toluene containing MEG-Cl (1000:1) in an inert $\left(\mathrm{N}_{2}\right)$ and anhydrous $\left(\mathrm{P}_{2} \mathrm{O}_{5}\right)$ atmosphere in glass vials. The sealed vials were then rotated for 90 min after which the crystals were rinsed with toluene. They were then sonicated in toluene for $5 \mathrm{~min}$, rinsed with deionized water, and dried under a stream of nitrogen, leaving MEG-Cl crystals.

Some MEG-Cl crystals were extended with the aptamer by creating a dilute aliquot of $1.3 \mu \mathrm{M}$ aptamer solution in deionized water $(750 \mu \mathrm{L}$ volume). The water solution was added to each test tube along with pyridine $(0.25 \mathrm{~mL})$ to have a ratio of 3:1 water solution: pyridine, and a $1 \mu \mathrm{M}$ final aptamer concentration. The test tubes were then placed on a spinning plate overnight. These crystals, now modified with MEG-Aptamer, were rinsed with deionized water and dried under a gentle $\mathrm{N}_{2}$ flow. The main steps in the preparation of the antifouling sensing layer at the surface of the EMPAS crystal are summarized in Scheme 1.

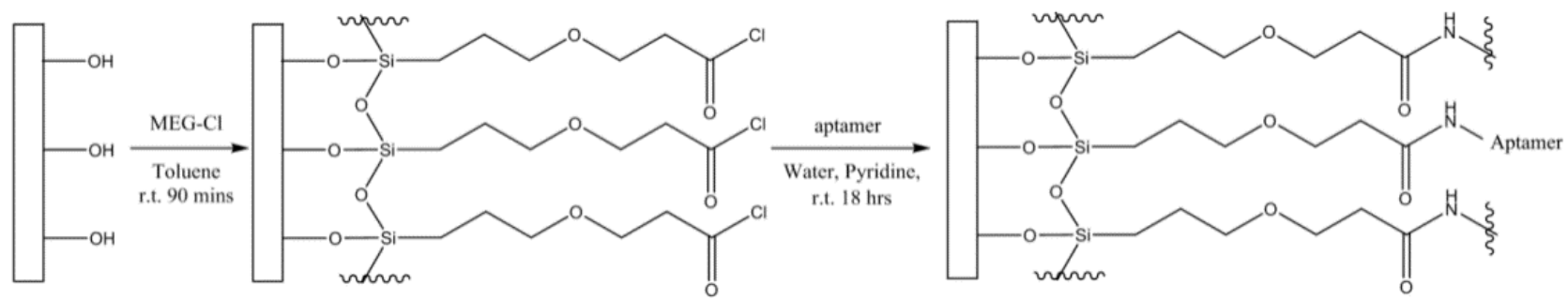

Scheme 1. Surface modification with MEG-Cl followed by extension with $\mathrm{N}_{\alpha}, \mathrm{N}_{\alpha}$-bis(carboxymethyl)L-lysine (ab-NTA) to form a MEG-Aptamer surface coating. 


\subsection{EMPAS Measurements}

EMPAS measurements were performed in either $10 \mathrm{mM}, \mathrm{pH} 7.4$ phosphate-buffered saline (PBS, $10 \mathrm{mM} \mathrm{Na}_{2} \mathrm{HPO}_{4}, 154 \mathrm{mM} \mathrm{NaCl}$ ), or UHT cow's milk. Bacteria were suspended in solution by first growing up a pre-culture of the chosen bacteria at $37^{\circ} \mathrm{C}$ overnight in Lysogeny Broth. Then, $1 \mathrm{~mL}$ of pre-culture was then centrifuged at 14,500 RPM for 5 min to pellet the bacteria. The bacteria pellet was then resuspended in $1 \mathrm{~mL}$ of PBS, after which the solution's optical density at $600 \mathrm{~nm}$ was measured by the UV-Vis spectrometer UV-1600PC (VWR International, Mississauga, Canada). The CFU was calculated from the optical density according to the following papers [31-33]. For samples in PBS, the resuspension was diluted to the desired concentration. For samples in milk, the resuspension was once again pelleted, the PBS removed, and the bacteria resuspended again in milk at the desired concentration.

Experimental performance of the EMPAS has been described previously [34]. After the standard set-up of the EMPAS, a bare, MEG-Cl coated, or MEG-Aptamer SAM-coated quartz crystal was installed in a custom flow-through cell, and PBS buffer was flowed over the crystal at a rate of $50 \mu \mathrm{L} / \mathrm{min}$.

An ultra-high frequency of $984 \mathrm{MHz}$ was used to perform the EMPAS measurements. The frequency was allowed to stabilize under PBS flow, after which $250 \mu \mathrm{L}$ of either PBS or milk sample containing a known concentration of bacteria was injected into the cell system by transferring the inlet tube to a vial containing the sample, before switching back to PBS. PBS buffer flow was continued to rinse the crystal surface of any loosely bound material. Once the frequency signal stabilized again, the experiment was stopped, and the frequency shift was calculated. The experiment was repeated in triplicate for each type of crystal.

\section{Results}

\subsection{Sensing of E. coli in PBS and Milk}

In the first series of experiments, we studied the kinetics of the changes in the frequency of the bare piezocrystal as well as those modified by antifouling MEG-Cl linker with attached DNA aptamers following interaction with various concentrations of $E$. coli in a PBS (Figure 1a) as well as in UHT cow's milk (Figure 1b). As can be seen from Figure 1a, the addition to the bare crystal of a relatively large concentration of E. coli $\left(10^{8} \mathrm{CFU} / \mathrm{mL}\right)$ in a buffer resulted in a sharp decrease of the resonant frequency $(17 \pm 4 \mathrm{kHz})$, which is evidence of non-specific adsorption of bacteria to the surface without coverage of antifouling layer. This high concentration was chosen to saturate the surface and show the maximum amount of potential fouling, and the change that would result from it.

However, a much smaller decrease in the frequency $(0.5 \pm 0.8 \mathrm{kHz})$ has been observed when the same E. coli concentration has been flowed over the surface of the piezocrystal modified by MEG-Cl linker. It is also clearly seen that with increased concentration of E. coli in a buffer added to the crystal surface covered by MEG-Aptamers, a decrease of the frequency was more significant. Similar results were obtained when instead of PBS the UHT milk had been used (Figure 1b). As can be seen from Figure 1b, the flow of the milk on the surface of bare crystal resulted in a sharp decrease in frequency due to non-specific adsorption of the milk components. However, the crystal covered by aptamers linked to MEG-Cl protects the piezoelectric transducer from substantial non-specific interactions. Although a certain decrease of resonant frequency was observed for milk flowed on the MEG-Aptamer surface, which is evidence of the matrix effect of milk components. The addition of the milk spiked by various concentrations of $E$. coli resulted in a decrease of the frequency when exposed to MEG-Aptamer crystals. 

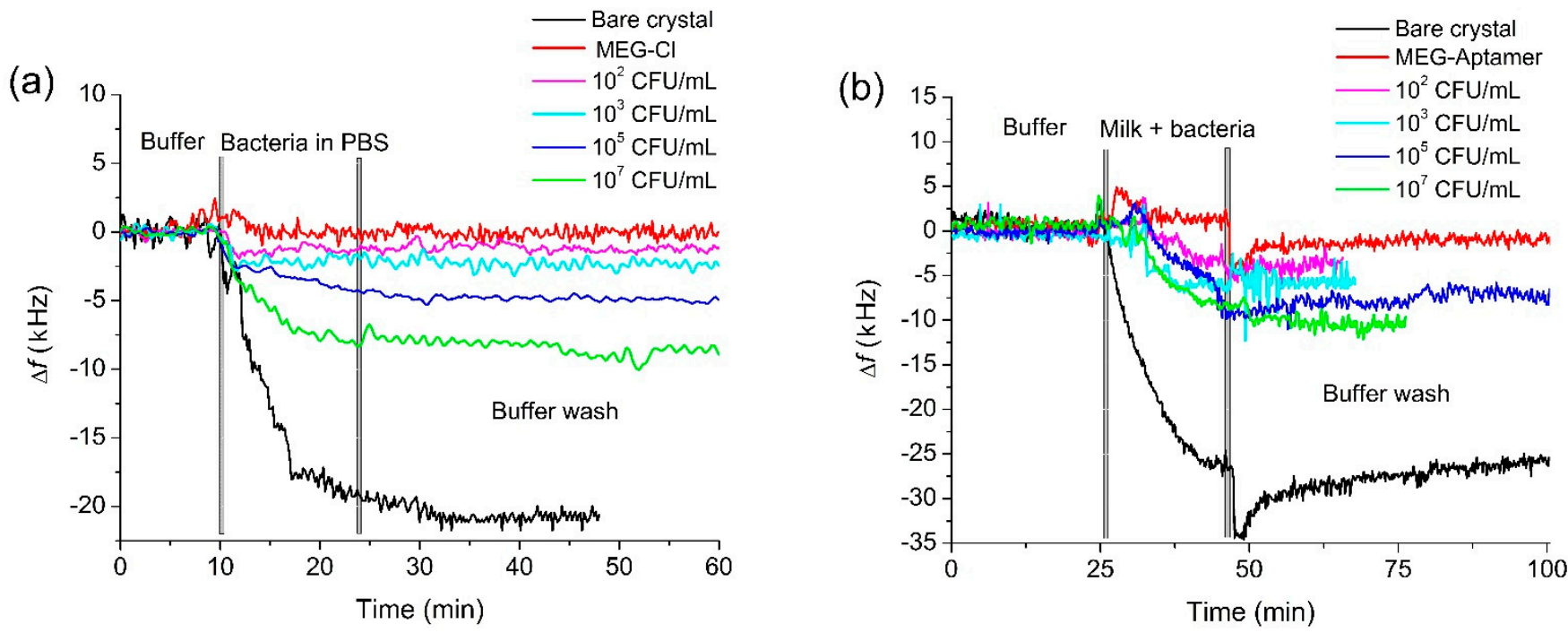

Figure 1. Plots showing the change in frequency, $\Delta \mathrm{f}$, vs. time for interaction of $E$. coli at various concentrations in PBS buffer (a) or in UHT cow's milk (b) to either a bare crystal, a crystal covered by MEG-Cl linker, as well as MEG-Aptamer-coated crystals. Bare and MEG-Cl coated crystals were exposed to $10^{8} \mathrm{CFU}$ E. coli, while MEG-Aptamer coated crystals were exposed to the concentrations specified in the legends.

The results are summarized in Table 1 and in Figure 2. The sensors' data were normalized to the average frequency of the crystal immediately prior to sample exposure, and the change in frequency after exposure was measured as the average of the final $5 \mathrm{~min}$ of readings after a suitable amount of wash-off in PBS. Such exposure always resulted in a decreased signal, however, for displaying the data, the frequency change, $\Delta f$, is stated in positive terms (Table 1, Figure 2).

Table 1. Frequency shifts for EMPAS crystals exposed to various concentrations of E. coli in either PBS or milk.

\begin{tabular}{cccc}
\hline Crystal Coating & $\boldsymbol{E . c o l i}(\mathrm{CFU} / \mathrm{mL})$ & $\boldsymbol{\Delta f}$ in PBS $(\mathbf{k H z})$ & $\boldsymbol{\Delta f}$ in Milk $(\mathbf{k H z})$ \\
\hline Bare & $1 \times 10^{8}$ & $17 \pm 4$ & $27 \pm 2$ \\
MEG-Cl & $1 \times 10^{8}$ & $0.5 \pm 0.8$ & $\mathrm{~N} / \mathrm{A}$ \\
MEG-Aptamer & 0 & $\mathrm{~N} / \mathrm{A}$ & $1.3 \pm 0.3$ \\
& $1 \times 10^{2}$ & $1.2 \pm 0.2$ & $3.0 \pm 0.7$ \\
$1 \times 10^{3}$ & $2.4 \pm 0.4$ & $5.0 \pm 0.2$ \\
& $1 \times 10^{5}$ & $4.8 \pm 0.1$ & $7.6 \pm 0.3$ \\
& $1 \times 10^{7}$ & $8.4 \pm 0.6$ & $10.7 \pm 0.2$ \\
\hline
\end{tabular}

When MEG-Aptamer-coated crystals were exposed to various concentrations of E. coli in either PBS or milk, a logarithmic trend was observed with quantification being possible at all measured concentrations (Figure 2).

For milk samples, there was a $1.3 \mathrm{kHz}$ change due to the milk, which was present for all concentrations of bacteria tested. Using the standard deviation of noise (signal-to-noise ratio: $\mathrm{S} / \mathrm{N}=3$ ) for a representative EMPAS experiment of approximately $126 \mathrm{~Hz}$, a theoretical LOD for E. coli in PBS of $35 \mathrm{CFU} / \mathrm{mL}$ was calculated as well as a limit of quantification (LOQ) of $146 \mathrm{CFU} / \mathrm{mL}$. These values are even lower in milk at 8 and $34 \mathrm{CFU} / \mathrm{mL}$ for the LOD and LOQ, respectively. 


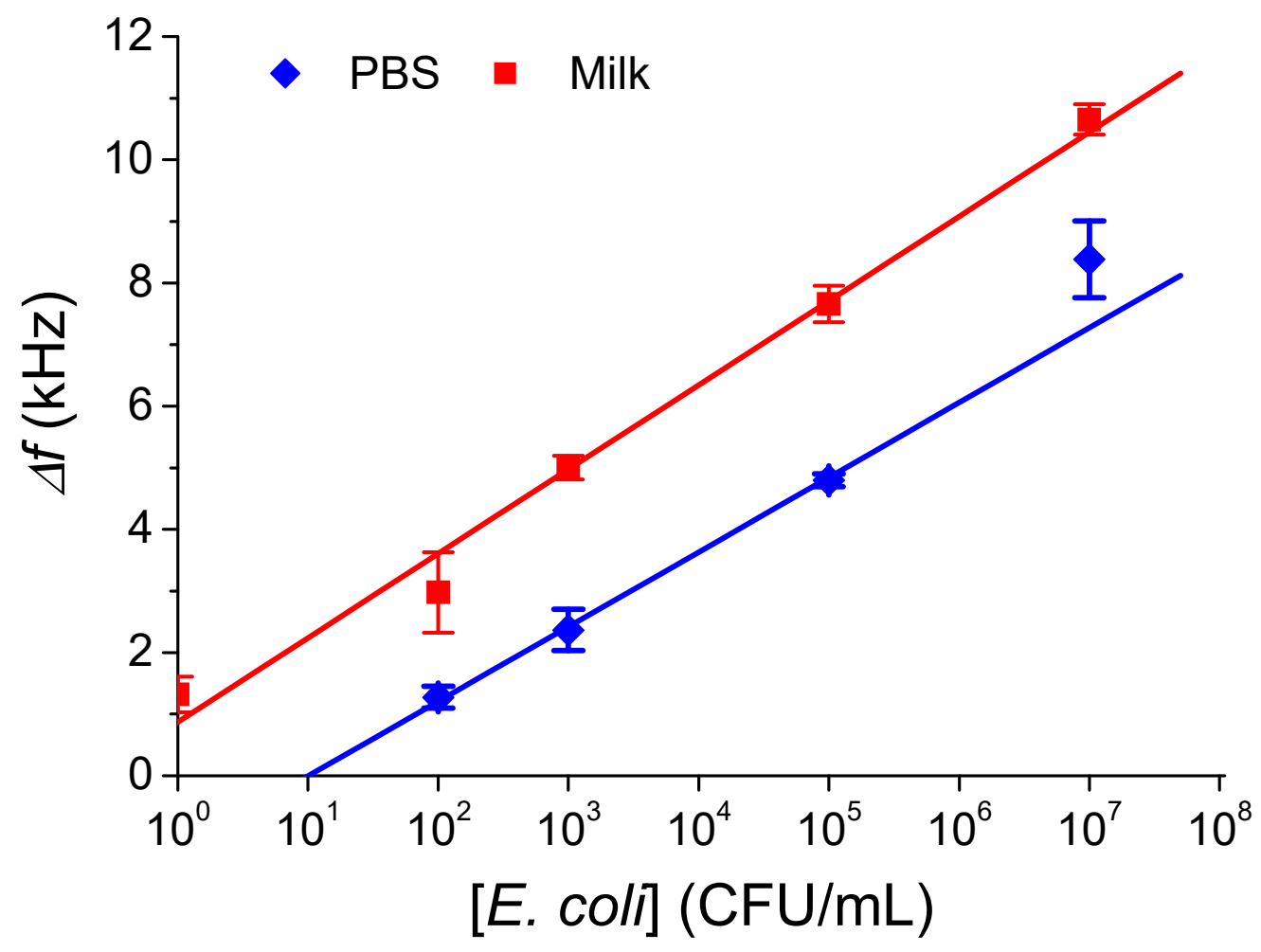

Figure 2. Frequency change, $\Delta f$, of EMPAS instrument for MEG-Aptamer-coated crystals after exposure to varying concentrations of $E$. coli in either PBS (blue diamonds) or milk (red squares) in log scale. Lines represent linear fits performed by OriginPro, version 7.5 (OriginLab Corporation, Northampton, MA, USA) with the following parameters: $\Delta f(\mathrm{kHz})=1.21 \log [$ E. coli $]-1.22, \mathrm{R}^{2}=0.995$ (PBS) and $\Delta f(\mathrm{kHz})=1.37 \log [$ E. coli $]+0.87, \mathrm{R}^{2}=0.994$ (Milk).

The obtained values are much lower in comparison with so far reported acoustic wave biosensors for $E$. coli detection, as discussed in the Introduction. As it is evident from the comparison of the calibration curve for E. coli detection in a PBS and in UHT cow's milk, there is a certain matrix effect of milk components that probably interact with the MEGAptamer coating. On the other hand, the configuration of the aptamer and consequently the binding properties can change in different environments. This effect requires additional analysis, for example, determination of the constant of association, $K_{d}$. For this purpose, we analyzed the binding properties of bacteria to the aptamers by means of fitting the binding curves constructed in a linear concentration scale by Langmuir isotherm [35]:

$$
\Delta f=(\Delta f)_{\max }\left[c /\left(K_{d}+c\right)\right]
$$

where $(\Delta f)_{\max }$ is the maximal frequency changes, $K_{d}$ is the constant of dissociation and $c$ is the concentration of bacteria. The lower the value of $K_{d}$ is, the stronger the complex aptamerbacteria is. It is convenient to present Equation (1) in the Lineweaver-Burk coordinates $(1 / \Delta f$ vs. $1 / c)$ :

$$
1 / \Delta f=K_{d} /(\Delta f)_{\max } \cdot c+1 /(\Delta f)_{\max }
$$

This plot is shown on Figure 3. By fitting the calibration curves in Figure 3 we obtained the following $K_{d}$ and $(\Delta f)_{\max }$ values for binding the bacteria to the aptamer in a buffer $\left(K_{d}=253.6 \pm 65.8 \mathrm{CFU} / \mathrm{mL} ;(\Delta f)_{\max }=4.4 \pm 1.5 \mathrm{kHz}\right)$ and in milk $\left(K_{d}=159.8 \pm 39.2 \mathrm{CFU} / \mathrm{mL}\right.$; $(\Delta f)_{\max }=7.5 \pm 1.4 \mathrm{kHz}$ ), respectively. It can be seen that the $K_{d}$ in milk is lower in comparison with those in PBS. We can speculate that one of the possible reasons (in addition to the matrix effect) can be certain changes in the conformation of the aptamers, which may improve the binding affinity. This is, however, only a preliminary assumption. More detailed analysis is 
therefore required, for example using circular dichroism or molecular dynamic simulations methods.

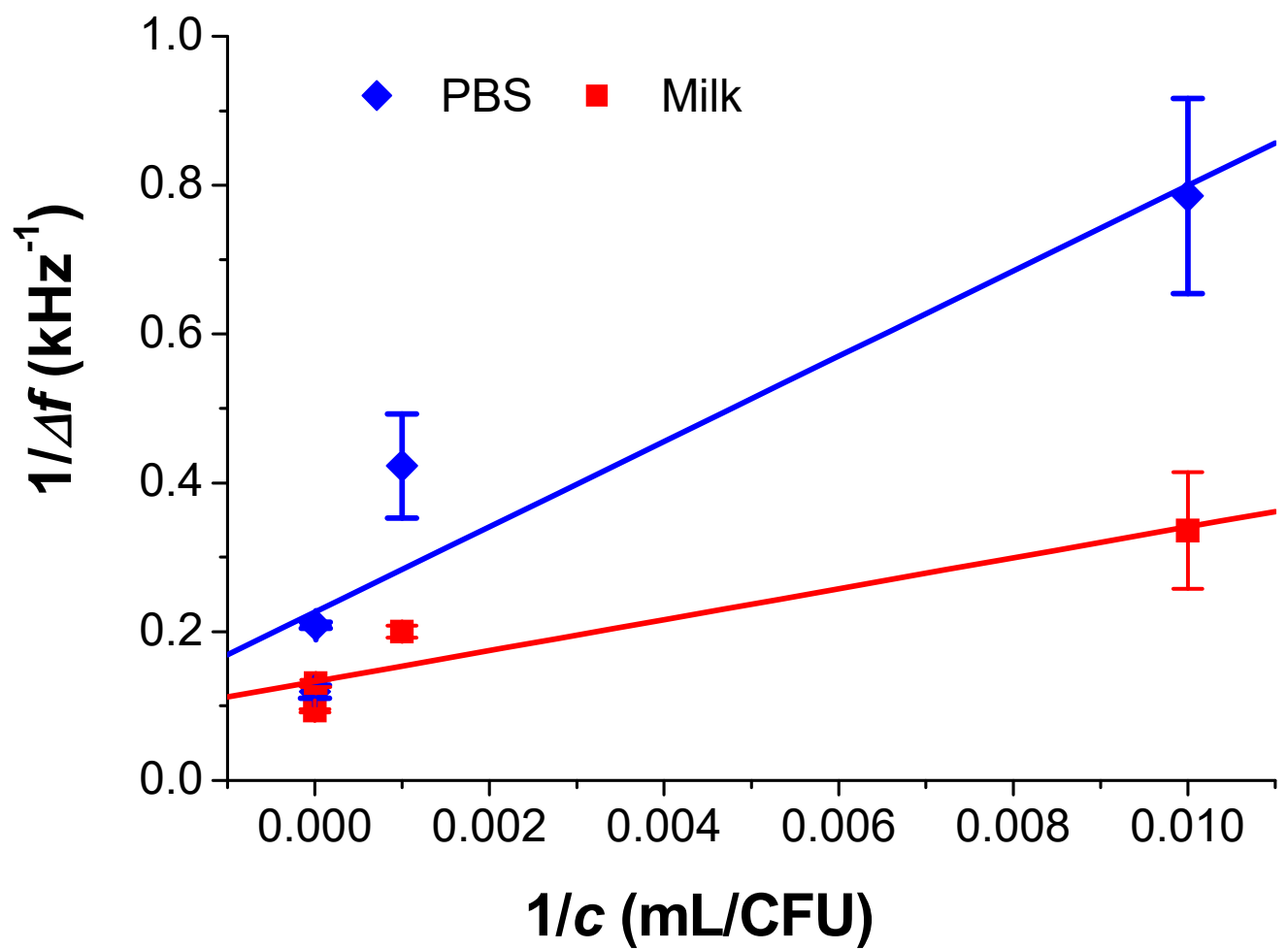

Figure 3. The Lineweaver-Burk plot of the frequency changes $(1 / \Delta f)$ vs. reverse concentration of $E$. coli $(1 / c)$ for aptasensor-based on DNA aptamers with antifouling properties. Lines represent linear fits performed by OriginPro, version 7.5 (OriginLab Corporation, Northampton, MA, USA) with the following parameters: $1 / \Delta f\left(\mathrm{kHz}^{-1}\right)=(57.33 \pm 14.88) / c\left(\mathrm{CFU}^{-1} \cdot \mathrm{mL} \cdot \mathrm{kHz}^{-1}\right)+(0.23 \pm 0.07)\left(\mathrm{kHz}^{-1}\right)$, $\mathrm{R}^{2}=0.939(\mathrm{PBS})$ and $1 / \Delta f\left(\mathrm{kHz}^{-1}\right)=(20.78 \pm 5.10) / c\left(\mathrm{CFU}^{-1} \cdot \mathrm{mL} \cdot \mathrm{kHz}^{-1}\right)+(0.13 \pm 0.03)\left(\mathrm{kHz}^{-1}\right)$, $\mathrm{R}^{2}=0.945$ (Milk).

\subsection{Testing the Selectivity of the Aptasensor}

To determine if the developed aptasensor was selective for E. coli bacteria, two additional species P. aeruginosa (PAO1) and S. aureus (Staph) were exposed in high concentrations $\left(1 \times 10^{8} \mathrm{CFU} / \mathrm{mL}\right)$ to unmodified EMPAS crystals and MEG-Aptamer crystals in a PBS (Figure 4). We used high concentrations of the bacteria, considering that at lower concentrations the interaction of these bacteria with MEG-Aptamer layers was negligibly small. As with previous measurements, the change in frequency is reported in positive values for visual clarity. From these measurements, PAO1 and Staph are both able to foul unmodified EMPAS crystals, though to a lesser extent than E. coli. PAO1 causes a larger change in frequency compared to Staph, suggesting a greater amount of fouling, which is to be expected based on a previous study [27]. In addition, the variance in fouling is quite high, which is expected since there is no specific attachment during these experiments.

Meanwhile, MEG-Aptamer-coated crystals show virtually no signal change after exposure to either PAO1 or Staph, with their standard deviations overlapping zero $\mathrm{Hz}$ in change. 


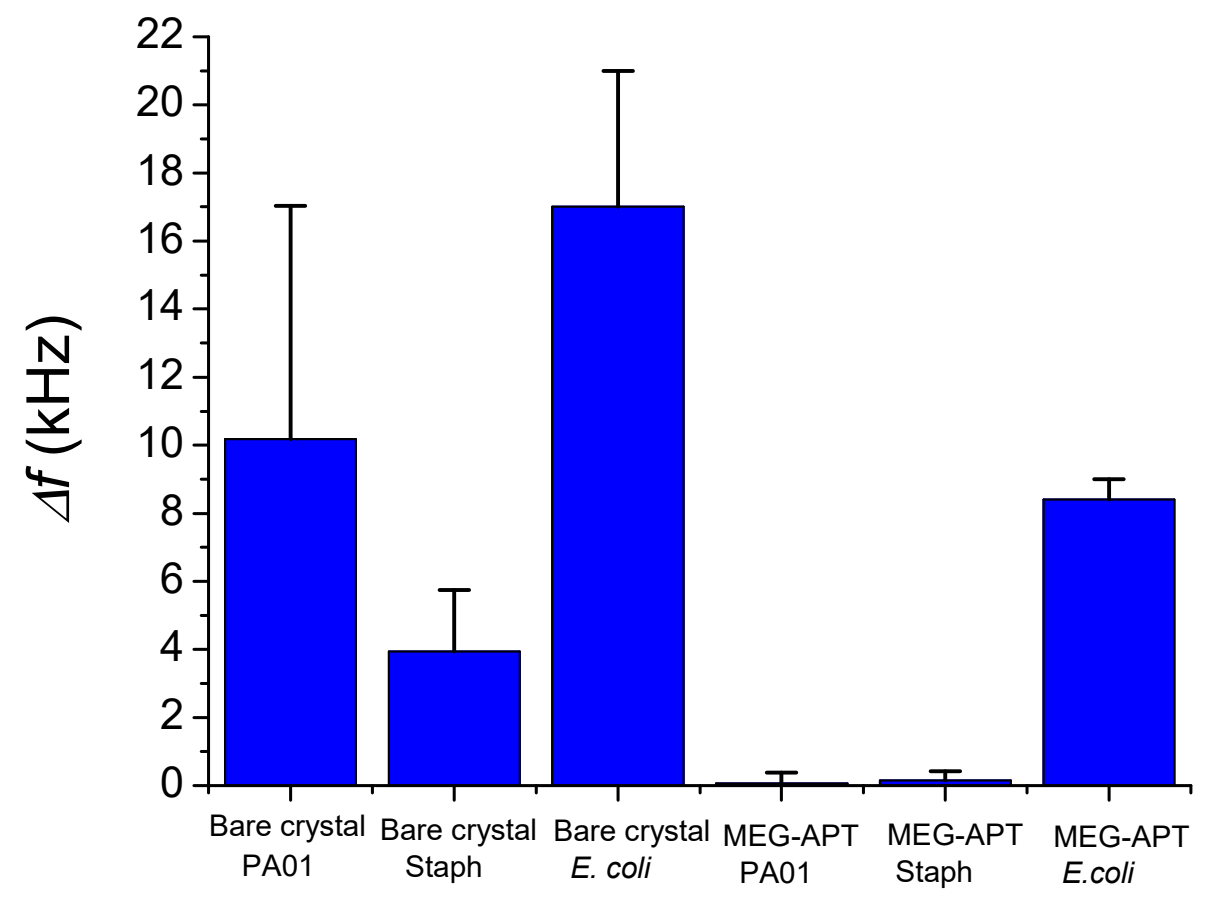

Figure 4. Change in frequency, $\Delta f$, for unmodified and MEG-Aptamer (MEG-APT) modified EMPAS crystals after exposure to either P. aeruginosa (PAO1), S. aureus (Staph) or E. coli in PBS. Concentrations of bacteria: $10^{8} \mathrm{CFU} / \mathrm{mL}$ (bare crystal), $10^{8} \mathrm{CFU} / \mathrm{mL}$ (PAO1 and Staph), $10^{7} \mathrm{CFU} / \mathrm{mL}$ (E. coli) (MEG-Aptamer).

\section{Discussion}

The primary purpose of the developed aptasensor is the detection of E. coli in solution. To determine if this was possible, EMPAS crystals were coated with MEG-Cl, which was further extended with the E. coli selective aptamer. The surface fouling observed on unmodified crystals from E. coli and from milk would make accurately quantifying the concentration of bacteria present extremely challenging as the fouling would cause large and unexpected changes in the signal.

As the MEG-Cl and MEG-Aptamer-coated crystals are capable of dramatic reductions in fouling, any signal change in sensor measurements can be attributed to the analyte of interest binding to the probe, and not as a result of fouling. This is very important in any biosensor measurement and suggests that MEG-Cl is a viable anti-fouling linker for these systems.

The logarithmic trend that results from increasing concentrations of E. coli in both PBS and milk is nearly identical when the $1.3 \mathrm{kHz}$ fouling from milk is accounted for. As such, quantification of $E$. coli in both media is possible. It is hypothesized that the logarithmic fit is a result of the surface packing of the large E. coli cells. As more and more cells are bound to the surface, this would greatly reduce the binding ability of further cells due to being blocked by previous cells. Further experiments, such as fluorescently staining the crystals after measurement and imaging them under microscopy, would need to be performed to test this hypothesis.

The EMPAS system itself would be difficult to implement in milk production facilities. A different biosensing device based on MEG-Cl and an E. coli aptamer could likely be created which would function to rapidly quantify bacterial contamination in milk samples.

When it comes to exposure of EMPAS crystals with other species of bacteria, the MEG-Aptamer-coated crystals show virtually no signal change after exposure to either PAO1 or Staph. The lack of signal change shows that the aptamer is unable to bind to these bacteria species and that the MEG-Cl coating prevents the bacteria from surface-fouling. This result indicates that the developed aptasensor is specific to E. coli and is likely able to 
function in the presence of other bacterial species, though confirmatory competition studies have yet to be performed.

As previously mentioned in the Introduction, existing acoustic wave-based aptasensors for E. coli achieved a LOD for E. coli several orders of magnitude higher than what was observed for the EMPAS-based aptasensor in this work. Moreover, in these papers, the aptasensors were not validated in milk samples. Thus, the EMPAS aptasensor revealed superior sensitivity for E. coli and allows the detection of bacteria in raw and undiluted milk samples. We should also emphasize that the sensor reported in this work has better or comparable sensitivity also in comparison with so far published electrochemical and optical sensors for detection of E. coli as it is evident from Table 2. However, no one sensor has been validated in not diluted milk samples.

Table 2. An overview of aptasensors used for the detection of E. coli.

\begin{tabular}{|c|c|c|c|c|c|c|}
\hline E. coli Strain & Material Platform & $\begin{array}{l}\text { Method of } \\
\text { Detection }\end{array}$ & $\begin{array}{l}\text { LOD, } \\
\text { CFU/mL }\end{array}$ & $\begin{array}{l}\text { Linear Range, } \\
\text { CFU/mL }\end{array}$ & Food Sample/Recovery \% & Reference \\
\hline \multicolumn{7}{|c|}{ Acoustic biosensors } \\
\hline $\begin{array}{l}8739 \text { (Crooks } \\
\text { strain) }\end{array}$ & Gold-thiolated aptamer & QCM & $10^{7}$ & NA & NA & [18] \\
\hline O157:H7 & $\begin{array}{l}\text { Gold-MHDA-streptavidin, } \\
\text { biotinylated aptamer } \\
\text { Gold-biotinylated thiol- }\end{array}$ & QCM & $1.46 \times 10^{3}$ & $5 \times 10^{2}-5 \times 10^{5}$ & NA & [13] \\
\hline КСТС 2571 & $\begin{array}{l}\text { Gold-biotinylated thiol- } \\
\text { streptavidin-biotinylated } \\
\text { aptamer }\end{array}$ & QCM & $10^{4}$ & $10^{5}-10^{8}$ & NA & {$[19]$} \\
\hline $\mathrm{DH} 5 \alpha$ & $\mathrm{SiO}_{2}$-MEG-NH${ }_{2}$-Aptamer & EMPAS & 8 & $10-10^{7}$ & Not diluted milk/127.4 & This work \\
\hline \multicolumn{7}{|c|}{ Electrochemical biosensors } \\
\hline O78:K80:H11 & SCPE/MWCNTs/TPA & EIS & 10 & $10-10^{6}$ & $\begin{array}{l}\text { Water, guava, litchi, mango } \\
\text { juices, milk/NA }\end{array}$ & [36] \\
\hline O157:H7 & $\mathrm{SCPE} / \mathrm{BC}-\mathrm{Ni}$ & EIS & 10 & $1-10^{5}$ & $\begin{array}{c}\text { Tap water, vegetable, carrot, } \\
\text { orange juices, stool/NA }\end{array}$ & {$[37]$} \\
\hline O157:H7 & 3D-IDEA & EIS & $2.9 \times 10^{2}$ & $10-10^{5}$ & Water/92.3 & [38] \\
\hline BL21 & IDE & EIS & 9 & $25-10^{3}$ & NA & [15] \\
\hline NA & $\begin{array}{c}\mathrm{Au} @ \mathrm{MoS}_{2}-\mathrm{PANI} \\
\text { nanocomposite }\end{array}$ & EIS, DPV & 10 & $10-10^{7}$ & Urine/90-110 & [39] \\
\hline CECT 675 & SWCNTs-RNA aptamers & Potentiometry & $6-26$ & $4-2.4 \times 10^{4}$ & $\begin{array}{l}\text { Filtrated milk, apple } \\
\text { juice/NA }\end{array}$ & [40] \\
\hline O157:H7 & $\begin{array}{c}\text { Gold- } \\
\text { Aptamer/MCH/MB@MI } \\
\text { nanocomposite }\end{array}$ & DPV & 32 & $10^{2}-10^{7}$ & Milk/88.1-115.3 & [41] \\
\hline \multicolumn{7}{|c|}{ Optical biosensors } \\
\hline O157:H7 & $\mathrm{CdSe} / \mathrm{ZnS}-\mathrm{QD}$ & Fluorescence & $10^{2}$ & $10^{2}-10^{7}$ & NA & [11] \\
\hline O157:H7 & PDA vesicles & Colorimetry & $10^{4}$ & $10^{4}-10^{8}$ & Fecal samples in PBS/NA & {$[42]$} \\
\hline O157:H7 & AuNPs & Colorimetry & $10^{5}$ & $10^{6}-10^{7}$ & NA & [43] \\
\hline ATCC 25922 & AuNPs & Colorimetry & $10^{5}$ & $10^{5}-10^{8}$ & Meat/NA & [44] \\
\hline O157:H7 & $\begin{array}{l}\text { Cu-MOF NPs/sandwich } \\
\text { assay with two aptamers }\end{array}$ & Colorimetry & 2 & $16-1.6 \times 10^{6}$ & $\begin{array}{l}\text { Milk/ filtrated/20x diluted } \\
\text { with water/96-102.6 } \\
\text { Coconut water, litchi juice }\end{array}$ & {$[45]$} \\
\hline MTCC 1698 & GO-AuNPs & Colorimetry & 10 & $10-10^{4}$ & $\begin{array}{l}\text { (both 10x diluted), bread } \\
\text { homogenized and } \\
\text { filtrated/NA }\end{array}$ & [46] \\
\hline O157:H7 & AuNPs & Colorimetry & 147 & $\begin{array}{c}1.2 \times 10^{2}-9 \times \\
10^{3}\end{array}$ & Tap water/90.2-96.7 & [47] \\
\hline
\end{tabular}

Abbreviations: 3D-IDEA: three-dimensional interdigitated electrode array; AuNPs: gold nanoparticles; BC-Ni: boron-carbon nanorods decorated by nickel nanoparticles; Cu-MOF NPs: copper-based metal-organic framework nanoparticles; DPV: differential pulse voltammetry; EMPAS: electromagnetic piezoelectric acoustic sensor; EIS: electrochemical impedance spectroscopy; GO-AuNPs: graphene oxide coated AuNPs; IDE: interdigitated electrode; MB: methylene blue; MCH: 6-mercaptohexanol; MI: magainin I; MHDA: 16-mercaptohexadecanoic acid; MWCNTs: multi-walled carbon nanotubes; PANI: polyaniline; PBS: phosphate buffer saline; PDA: polydiacetylene; QCM: quartz crystal microbalance; QD: quantum dot; SCPE: screen printed electrode; SWCNTs: single-walled carbon nanotubes; TPA: terephthalaldehyde.

The present work strongly suggests that a biosensor using MEG-Cl as an anti-fouling surface linker in combination with an aptamer selective to the bacteria of choice, in this case, E. coli, could be developed and used to rapidly quantify bacteria in real-world samples. Such a detection system could greatly increase the safety of milk worldwide, as unsafe levels of bacteria could be rapidly determined, and contaminated milk samples removed from sale. 


\section{Conclusions}

The developed aptamer-based sensor using MEG-Cl as an anti-fouling surface linker was able to successfully detect and quantify the presence of E. coli bacteria in PBS and milk samples. The sensor was found to drastically reduce fouling of bacteria and milk to the crystal surface, allowing for the selective measurement of E. coli in the samples. The limit of quantification of $34 \mathrm{CFU} / \mathrm{mL}$ in milk samples is well below the safe limit for bacteria allowed in milk products in the EU, suggesting that such a sensor would be applicable in the milk industry. In addition, the near-complete lack of signal observed for the sensor when exposed to competing bacteria species $P$. aeruginosa and $S$. aureus shows that the sensor is selective to the desired species for detection. The existing EMPAS device requires an advance in design engineering to render it more user-friendly. Nevertheless, this work has clearly demonstrated that a more robust sensor using MEG-Cl and a bacteria-sensitive aptamer could be successfully developed for practical employment in the dairy industry for rapid evaluation of milk samples.

Author Contributions: Conceptualization, S.S., B.D.L.F., M.T. and T.H.; formal analysis, S.S., B.D.L.F., K.D. and T.H.; investigation, S.S. and K.D.; methodology, S.S., B.D.L.F., K.D., M.T. and T.H.; validation, S.S.; funding acquisition, M.T. and T.H.; project administration, M.T. and T.H.; software, B.D.L.F.; supervision, M.T. and T.H.; writing-original draft, S.S., B.D.L.F. and K.D.; writing-review \& editing, S.S., B.D.L.F., K.D., T.H. and M.T. All authors have read and agreed to the published version of the manuscript.

Funding: A portion of this research was conducted at the Lash Miller Chemical Laboratories, University of Toronto. This work was funded under European Union's Horizon 2020 research and innovation program through the Marie Skłodowska-Curie grant agreement No 101007299 and by Science Agency VEGA, project No. 1/0419/20 (to T.H.). Support for this work was also provided by the Natural Sciences and Engineering Council of Canada, grant No. 9522 (to M.T.).

Institutional Review Board Statement: Not applicable.

Informed Consent Statement: Not applicable.

Data Availability Statement: Not applicable.

Conflicts of Interest: The authors declare no conflict of interest.

\section{References}

1. Milk and Milk Product Statistics. Available online: https://ec.europa.eu/eurostat/statistics-explained/index.php?title=Milk_ and_milk_product_statistics (accessed on 29 November 2021).

2. World Health Organization; Food and Agriculture Organization of the United Nations. Shiga Toxin-Producing Escherichia coli (STEC) and Food: Attribution, Characterization, and Monitoring; World Health Organization: Geneva, Switzerland, 2018.

3. Ballem, A.; Gonçalves, S.; Garcia-Meniño, I.; Flament-Simon, S.C.; Blanco, J.E.; Fernandes, C.; Saavedra, M.J.; Pinto, C.; Oliveira, H.; Blanco, J.; et al. Prevalence and serotypes of Shiga toxin-producing Escherichia coli (STEC) in dairy cattle from Northern Portugal. PLoS ONE 2020, 15, e0244713. [CrossRef] [PubMed]

4. EFSA Panel on Biological Hazards (EFSA BIOHAZ Panel). Scientific Opinion on the public health risks related to the consumption of raw drinking milk. EFSA J. 2015, 13, 3940. [CrossRef]

5. Mir, R.A.; Kudva, I.T. Antibiotic-resistant Shiga toxin-producing Escherichia coli: An overview of prevalence and intervention strategies. Zoonoses Public Health 2019, 66, 1-13. [CrossRef] [PubMed]

6. Milk Quality: Bacterial Contamination. Available online: https://www.teagasc.ie/media/website/animals/dairy/Bacteria.pdf\#: $\sim\{\}:$ text=EU\%20legislation $\% 20$ indicates $\% 20$ that $\% 20$ total $\% 20$ bacterial $\% 20$ count $\% 20 \% 28 \mathrm{TBC} \% 29$, counts $\% 20$ of $\% 20$ greater $\% 20$ than $\% 201 \% 2 \mathrm{C} 000 \% 2 \mathrm{Fml} \% 20$ are $\% 20$ generally\%20penalised (accessed on 29 November 2021).

7. Chye, F.Y.; Abdullah, A.; Ayob, M.K. Bacteriological quality and safety of raw milk in Malaysia. Food Microbiol. 2004, $21,535-541$. [CrossRef]

8. Ali, M.A.; Elsherbiny, M.E.; Emara, M. Updates on aptamer research. Int. J. Mol. Sci. 2019, 20, 2511. [CrossRef]

9. Bu, S.J.; Wang, K.Y.; Bai, H.S.; Leng, Y.; Ju, C.J.; Wang, C.Y.; Liu, W.S.; Wan, J.Y. Immunoassay for pathogenic bacteria using platinum nanoparticles and a hand-held hydrogen detector as transducer. Application to the detection of Escherichia coli $\mathrm{O}_{157}: \mathrm{H}_{7}$. Mikrochim. Acta 2019, 186, 296. [CrossRef]

10. Subjakova, V.; Oravczova, V.; Tatarko, M.; Hianik, T. Advances in electrochemical aptasensors and immunosensors for detection of bacterial pathogens in food. Electrochim. Acta 2021, 389, 138724. [CrossRef] 
11. Demirkol, D.O.; Timur, S. A sandwich-type assay based on quantum dot/aptamer bioconjugates for analysis of $E$. coli $\mathrm{O}_{157}: \mathrm{H}_{7}$ in microtiter plate format. Int. J. Polym. Mater. Polym. Biomater. 2016, 65, 85-90. [CrossRef]

12. Denny, J.; Bhat, M.; Eckman, K. Outbreak of Escherichia coli $\mathrm{O}_{157}: \mathrm{H}_{7}$ associated with raw milk consumption in the Pacific northwest. Foodborne Path. Dis. 2008, 5, 321-328. [CrossRef]

13. Yu, X.; Chen, F.; Wang, R.; Li, Y. Whole-bacterium SELEX of DNA aptamers for rapid detection of E. coli $\mathrm{O}_{157}: \mathrm{H}_{7}$ using a QCM sensor. J. Biotechnol. 2018, 266, 39-49. [CrossRef]

14. Zou, Y.; Duan, N.; Wu, S.; Shen, M.; Wang, Z. Selection, identification, and binding mechanism studies of an ssDNA aptamer targeted to different stages of E. coli $\mathrm{O}_{157}: \mathrm{H}_{7}$. J. Agricult. Food Chem. 2018, 66, 5677-5682. [CrossRef] [PubMed]

15. Abdelrasoul, G.N.; Anwar, A.; MacKay, S.; Tamura, M.; Shah, M.A.; Khasa, D.P.; Montgomery, R.R.; Ko, A.I.; Chen, J. DNA aptamer-based non-faradaic impedance biosensor for detecting E. coli. Anal. Chim. Acta 2020, 1107, 135-144. [CrossRef] [PubMed]

16. Zhao, Y.-W.; Wang, H.-X.; Jia, G.-C.; Li, Z. Application of aptamer-based biosensor for rapid detection of pathogenic Escherichia coli. Sensors 2018, 18, 2518. [CrossRef] [PubMed]

17. Melikishvili, S.; Piovarci, I.; Hianik, T. Advances in colorimetric assay based on AuNPs modified by proteins and nucleic acid aptamers. Chemosensors 2021, 9, 281. [CrossRef]

18. Urmann, K.; Bahnemann, J.; Chikneyan, Z.; Kasmaee, L.M.; Hoffmann, M.R. Electromechanical detection of pathogens with self-assembled nucleic acid biosensors. TechConnect Briefs 2018, 2, 153-156.

19. Khobragade, S.; Da Silva Granja, C.; Sandström, N.; Efimov, I.; Ostanin, V.P.; van der Wijngaart, W.; Klenerman, D.; Ghosh, S.K. Direct detection of whole bacteria using a nonlinear acoustic resonator. Sens. Actuat. B Chem. 2020, 316, 128086. [CrossRef]

20. Ballantyne, S.M.; Thompson, M. Superior analytical sensitivity of electromagnetic excitation compared to contact electrode instigation of transverse acoustic waves. Analyst 2004, 129, 219-224. [CrossRef]

21. Thompson, M.; Blaszykowski, C.; Sheikh, S.; Rodriguez-Emmenegger, C.; De Los Santos Pereira, A. Biological Fluid-Surface Interactions. Detection and Medical Devices; RSC Detection Science Series; Royal Society of Chemistry: Cambridge, UK, 2017.

22. Banerjee, I.; Pangule, R.C.; Kane, R.S. Antifouling coatings: Recent developments in the design of surfaces that prevent fouling by proteins, bacteria, and marine organisms. Adv. Mater. 2011, 23, 690-718. [CrossRef]

23. Blaszykowski, C.; Sheikh, S.; Thompson, M. Surface chemistry to minimize fouling from blood-based fluids. Chem. Soc. Rev. 2012, 41, 5599-5612. [CrossRef]

24. Damodaran, V.B.; Murthy, N.S. Bio-inspired strategies for designing antifouling biomaterials. Biomater. Res. 2016, $20,18$. [CrossRef]

25. Sheikh, S.; Yang, D.Y.; Blaszykowski, C.; Thompson, M. Single ether group in a glycol-based ultra-thin layer prevents surface fouling from undiluted serum. Chem. Commun. 2012, 48, 1305-1307. [CrossRef]

26. Fedorov, K.; Jankowski, A.; Sheikh, S.; Blaszykowski, C.; Reheman, A.; Romaschin, A.; Ni, H.; Thompson, M. Prevention of surface-induced thrombogenesis on poly(vinyl chloride). J. Mater. Chem. B 2015, 3, 8623. [CrossRef] [PubMed]

27. De La Franier, B.; Asker, D.; van den Berg, D.; Hatton, B.; Thompson, M. Reduction of microbial adhesion on polyurethane by a sub-nanometer covalently-attached surface modifier. Coll. Surf. B Biointerfaces 2021, 200, 111579. [CrossRef] [PubMed]

28. De La Franier, B.; Jankowski, A.; Thompson, M. Functionalizable self-assembled trichlorosilyl-based monolayer for application in biosensor technology. Appl. Surf. Sci. 2017, 414, 435-441. [CrossRef]

29. Spagnolo, S.; De La Franier, B.; Hianik, T.; Thompson, M. Surface probe linker with tandem anti-fouling properties for application in biosensor technology. Biosensors 2020, 10, 20. [CrossRef]

30. Bruno, J.G.; Carrillo, M.P.; Phillips, T.; Andrews, C.J. A novel screening method for competitive FRET-aptamers applied to E. coli assay development. J. Fluoresc. 2010, 20, 1211-1223. [CrossRef] [PubMed]

31. Fang, W.; Zhang, H.; Wang, X.; Wei, W.; Shen, Y.; Yu, J.; Liang, J.; Zheng, J.; Shen, Y. Facile synthesis of tunable plasmonic silver core/magnetic $\mathrm{Fe}_{3} \mathrm{O}_{4}$ shell nanoparticles for rapid capture and effective photothermal ablation of bacterial pathogens. New $\mathrm{J}$. Chem. 2017, 41, 10155-10164. [CrossRef]

32. Fang, W.; Han, C.; Zhang, H.; Wei, W.; Liu, R.; Shen, Y. Preparation of amino-functionalized magnetic nanoparticles for enhancement of bacterial capture efficiency. RSC Adv. 2016, 6, 67875-67882. [CrossRef]

33. Xing, J.; Ma, L.; Cheng, X.; Ma, J.; Wang, R.; Xu, K.; Mymryk, J.S.; Zhang, Z. Expression and functional analysis of the argonaute protein of thermus thermophilus (TtAgo) in E. coli BL21 (DE3). Biomolecules 2021, 11, 524. [CrossRef]

34. de los Santos Pereira, A.; Sheikh, S.; Blaszykowski, C.; Pop-Georgievski, O.; Fedorov, K.; Thompson, M.; Rodriguez-Emmenegger, C. Antifouling polymer brushes displaying antithrombogenic surface properties. Biomacromolecules 2016, 17, 1179-1185. [CrossRef]

35. Wilson, B.D.; Soh, H.T. Re-evaluation the conventional wisdom about binding assays. Trends Biochem. Sci. 2020, 45, 639-649. [CrossRef] [PubMed]

36. Kaur, H.; Shorie, M.; Sharma, M.; Ganguli, A.K.; Sabherwal, P. Bridged rebar graphene functionalized aptasensor for pathogenic E. coli $\mathrm{O}_{78}: \mathrm{K}_{80}: \mathrm{H}_{11}$ detection. Biosens. Bioelectron. 2017, 98, 486-493. [CrossRef] [PubMed]

37. Kaur, H.; Shorie, M.; Sabherwal, P. Electrochemical aptasensor using boron-carbon nanorods decorated by nickel nanoparticles for detection of E. coli O157:H7. Microchim. Acta 2020, 187, 461. [CrossRef] [PubMed]

38. Brosel-Oliu, S.; Ferreira, F.; Uria, N.; Abramova, N.; Gargallo, R.; Muñoz-Pascual, F.Y.; Bratov, A. Novel impedimetric aptasensor for label-free detection of Escherichia coli $\mathrm{O}_{157}: \mathrm{H}_{7}$. Sens. Actuat. B Chem. 2018, 255, 2988-2995. [CrossRef]

39. Raj, P.; Oh, M.H.; Han, K.; Lee, T.Y. Label-free electrochemical biosensor based on Au@MoS ${ }_{2}-$ PANI for Escherichia coli detection. Chemosensors 2021, 9, 49. [CrossRef] 
40. Zelada-Guillén, G.A.; Bhosale, S.V.; Riu, J.; Rius, F.X. Real-time potentiometric detection of bacteria in complex samples Anal. Chem. 2010, 82, 9254-9260. [CrossRef]

41. Bu, S.; Wang, K.; Li, Z.; Wang, C.; Hao, Z.; Liu, W.; Wan, J. An electrochemical biosensor based on methylene blue-loaded nanocomposites as signal-amplifying tags to detect pathogenic bacteria. Analyst 2020, 145, 4328. [CrossRef]

42. Zhang, J.; Zheng, M.; Zhong, Y.; Yang, J.; Zhao, Y.; Wu, W.; Ye, W.; Wen, J.; Wang, Q.; Lu, J. An aptamer-based biosensor for colorimetric detection of Escherichia coli $\mathrm{O}_{157}: \mathrm{H}_{7}$. PLoS ONE 2012, 7, e48999. [CrossRef]

43. Wu, W.H.; Li, M.; Wang, Y.; Ouyang, H.X.; Wang, L.; Li, C.X.; Cao, Y.C.; Meng, Q.H.; Lu, J.X. Aptasensors for rapid detection of Escherichia coli $\mathrm{O}_{157}: \mathrm{H}_{7}$ and Salmonella typhimurium. Nanosci. Res. Lett. 2012, 7, 658-665. [CrossRef]

44. Ledlod, S.; Areekit, S.; Santiwatanakul, S.; Chansiri, K. Colorimetric aptasensor for detecting Salmonella spp., Listeria monocytogenes, and Escherichia coli in meat samples. Food Sci. Technol. Int. 2020, 26, 430-443. [CrossRef]

45. Duan, N.; Yang, W.; Wu, S.; Zou, Y.; Wang, Z. A visual and sensitive detection of Escherichia coli based on aptamer and peroxidase-like mimics of copper-metal organic framework nanoparticles. Food Anal. Meth. 2020, 13, 1433-1441. [CrossRef]

46. Gupta, R.; Kumar, A.; Kumar, S.; Kumar Pinnaka, A.; Kumar Singhal, N. Naked eye colorimetric detection of Escherichia coli using aptamer conjugated graphene oxide enclosed gold nanoparticles. Sens. Actuat. B Chem. 2021, 329, 129100. [CrossRef]

47. Xie, Y.; Huang, Y.; Li, J.; Wu, J. A trigger-based aggregation of aptamer-functionalized gold nanoparticles for colorimetry: An example on detection of Escherichia coli $\mathrm{O}_{157}: \mathrm{H}_{7}$. Sens. Actuat. B Chem. 2021, 339, 129865. [CrossRef] 